\title{
Experimental intra-ovum infection of coho salmon (Oncorhynchus kisutch) eggs with Renibacterium salmoninarum using a microinjection technique
}

\author{
L. L. Brown ${ }^{1}$, R. Ricks ${ }^{2}$, T. P. T. Evelyn ${ }^{2}$, L. J. Albright ${ }^{1}$ \\ ${ }^{1}$ Institute of Aquaculture Research, Department of Biological Sciences, Simon Fraser University, Burnaby, \\ British Columbia, Canada V5A 1 S6 \\ ${ }^{2}$ Department of Fisheries and Oceans, Fisheries Research Branch, Pacific Biological Station, Nanaimo, \\ British Columbia, Canada V9R 5K6
}

\begin{abstract}
Renibacterium salmoninarum, the causative agent of bacterial kidney disease in salmonids, is transmitted from parent to progeny via the egg. Natural intra-ovum infection rates are low, making it necessary to use large sample sizes when attempting any conclusions on the efficacy of treatments to eliminate these infections. To obviate this problem, a microinjection technique was developed for inducing intra-ovum infections at high prevalence. The technique, described in this paper, required the use of relatively inexpensive equipment, resulted in good egg survival rates ( $73 \%$ to the eyed stage), and ensured high intra-ovum infection rates: 91 and $82 \%$ at the eyed and alevin stages, respectively.
\end{abstract}

\section{INTRODUCTION}

The causative agent of bacterial kidney disease (BKD) in salmonids, Renibacterium salmoninarum (Rs) (Sanders \& Fryer 1980), can be transmitted vertically via the salmonid egg (Bullock et al. 1978), the pathogen being carried intra-ovum (Evelyn et al. 1984a, b. 1986b). Infected coelomic fluid has been shown to be an important source of the intra-ovum infections (Evelyn et al. 1986b). The infections apparently occur following ovulation and via the micropyle (Evelyn et al. $1984 a, 1986 a)$. Intra-ovum infection rates appear to be low (ca 6 to $15 \%$ ), even when eggs are derived from heavily infected spawners (Evelyn et al. 1984a, b, 1986c). Thus, in evaluating techniques for preventing or eliminating intra-ovum infections, large sample sizes must be used if statistically valid conclusions are to be drawn.

To obviate the need for large sample sizes, we developed a simple microinjection technique for establishing infections at high prevalence in salmonid eggs. The technique avoids the use of expensive micromanipulators normally used in microinjection procedures (Metcalfe \& Sonstegard 1984, Black et al. 1985), and resulted in statisfactory egg survival and high infection rates. The purpose of this paper is to describe the technique.

\section{MATERIALS AND METHODS}

Eggs and milt. Eggs were taken from coho salmon (Oncorhynchus kisutch) that had returned from the sea to spawn at the Capilano Hatchery (Department of Fisheries and Oceans) in North Vancouver, British Columbia, Canada. The fish were grossly normal by external and internal examination. Indirect fluorescent antibody tests (IFAT) and culture (Bullock \& Stuckey 1975. Daly \& Stevenson 1985) performed on ovarian fluid and milt failed to detect any Rs cells. Eggs and milt were transported to the laboratory in separate, sterile, iced, plastic containers that had been filled with oxygen before transport to ensure viability.

Bacteria. Rs isolate 384 , grown for $21 \mathrm{~d}$ at $15^{\circ} \mathrm{C}$ on charcoal agar (SKDM-C) (Daly \& Stevenson 1985) that was modified by the addition of antibiotics (Austin et al. 1983), was used to infect eggs (Evelyn et al. 1986b). The resultant growth was aseptically scraped off culture plates and suspended in sterile peptone-saline (P-S; 0.1-0.85\%, respectively). The turbidity of the 
suspension was adjusted to $2.0 \mathrm{OD}$ at $420 \mathrm{~nm}$ (equivalent to ca $1 \times 10^{8}$ cells $\mathrm{ml}^{-1}$ ). The suspension was then diluted with sterile P-S, to give a bacterial cell concentration of ca $1 \times 10^{3}$ cells $\mathrm{ml}^{-1}$, and kept on ice until used.

Microinjection procedure. Non-water-hardened eggs were placed in shallow wells $(7 \mathrm{~mm}$ diam. $\times 3$ to $5 \mathrm{~mm}$ deep) that had been drilled into a plexiglass block. Sufficient ovarian fluid (ca $0.5 \mathrm{ml}$ ) was placed in the wells with the eggs to prevent drying.

Microinjection was performed using a glass, unheparinized $25 \mu \mathrm{l}$ hematocrit tube (Drummond), one end of which had been pulled to a tapered tip of not more than $10 \mu \mathrm{m}$ bore size using a microelectrode puller (Industrial Science Associates, Ridgewood, N.Y.). The glass needle was autoclaved, slipped over a 23 gauge 'LuerLok' disposable needle (Becton-Dickinson) and attached securely with silicon glue. Using the Luer attachment, the needle apparatus was fixed to a $50 \mu \mathrm{l}$ syringe (Hamilton), secured to a push-button dispenser (Hamilton) which depressed the syringe plunger by $1 / 50$ th of the total syringe volume, thus releasing $1 \mu l$ of

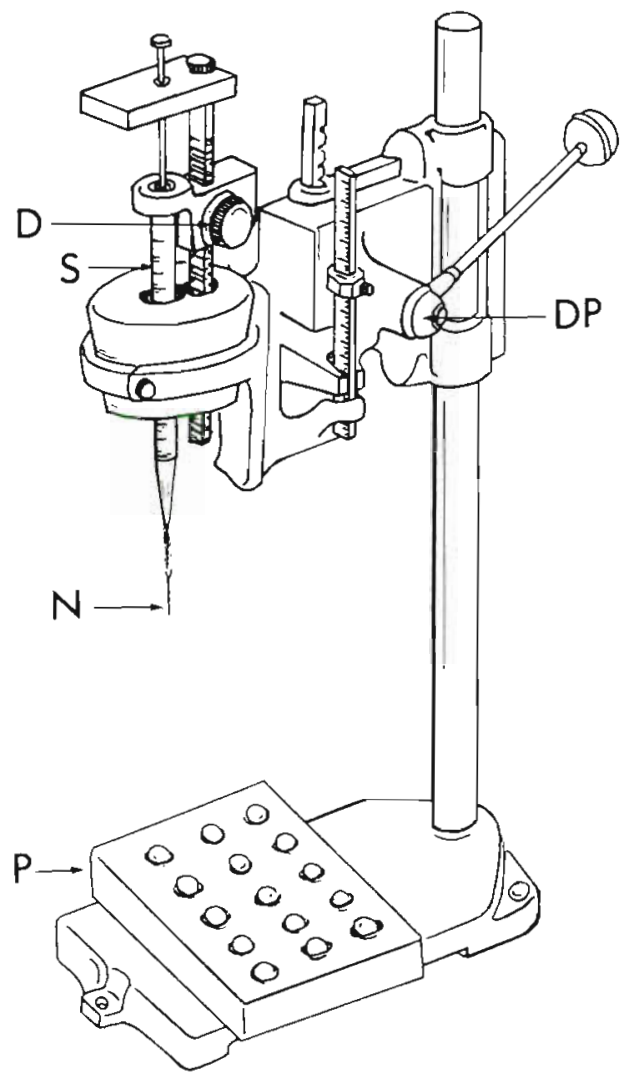

Fig. 1 Schematic diagram of the microinjection apparatus used in Expt 1. The $50 \mu l$ syringe (S) is attached to an automatic dispenser (D), and fitted with a glass needle (N). The syringe and needle assembly are brought to the eggs via a modified drill press (DP). Eggs are held in wells in a plexiglass block $(\mathrm{P})$

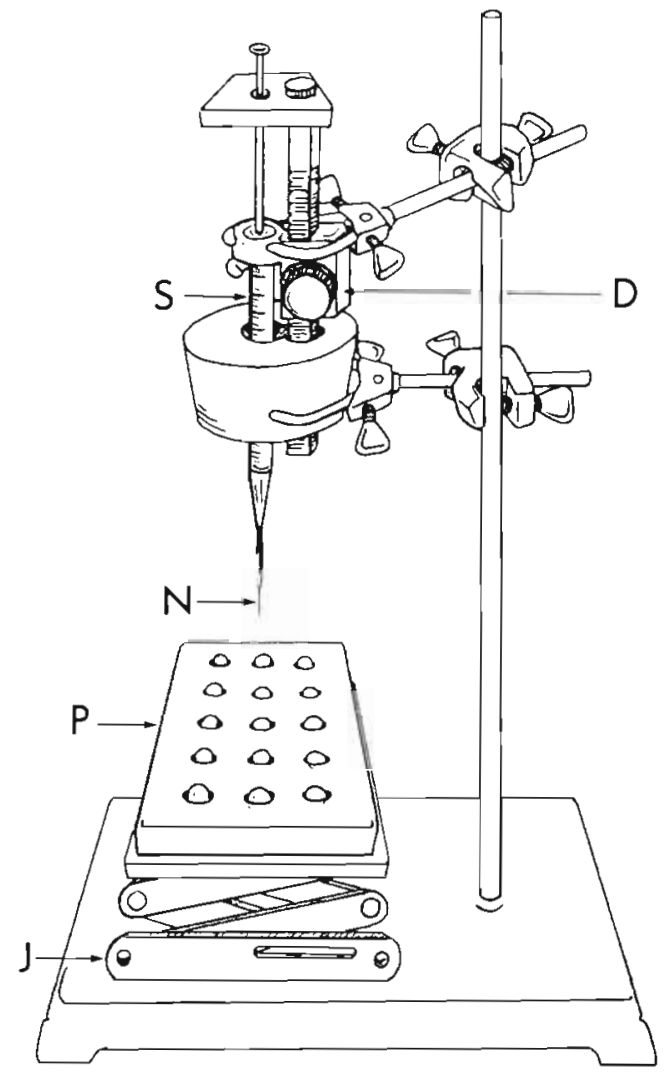

Fig. 2. Schematic diagram of the microinjection apparatus used in Expt 2. The 50 ul syringe ( $S$ ) is attached to an automatic dispenser (D), and fitted with a glass needle (N). Eggs held in wells in a plexiglass block $(\mathrm{P})$ are raised to the needle via a labjack (J)

solution at each push of the button. The entire syringe assembly was held in place by a Size $10^{1 / 2}$ rubber stopper that was mounted in one of 2 ways. The first utilized a small, modified drill press (Dremel, Racine, Wisconsin) (Fig. 1). By operating the press, the syringe was gently lowered until the needle punctured the egg membrane. An adjustable stop on the drill press ensured that the needle pierced the egg to a depth of only ca 1 to $2 \mathrm{~mm}$. One microlitre of the solution was then injected into the yolk. The second method was a modification of the first. The syringe assembly was tightly clamped to a support stand and the plexiglass egg holder placed on a small 'labjack' (Fisher Scientific). The labjack was gently raised until the egg membrane was pierced by the stationary glass needle (see Fig. 2). Here, the depth to which the needle pierced the egg was estimated by eye and kept to 1 to $2 \mathrm{~mm}$. Again. $1 \mu \mathrm{l}$ of bacterial suspension was administered to each egg.

Using either technique, 30 to 40 eggs could be injected with one syringe in ca $2 \mathrm{~min}$. The glass needle/ disposable needle assembly was removed and replaced 
after the syringe had been emptied. A new assembly was then attached to the refilled syringe, air bubbles removed, and egg injection resumed.

Experiments. Two experiments were performed. The first was to compare survival in injected and uninjected eggs. Eggs were taken from 1 coho salmon and divided into 3 groups of 30 eggs each. The first group was injected with sterile P-S $\left(1 \mu \mathrm{egg}^{-1}\right)$. The second group was punctured with a glass needle but no P-S was injected. The third group was left untreated. The apparatus shown in Fig. 1 was used for this experiment.

The three groups of eggs were placed in clean dry beakers ( 1 beaker group ${ }^{-1}$ ) on ice. Milt from a coho salmon (ca $0.5 \mathrm{ml}$ milt per 30 eggs) was then added. After 1 min, eggs were rinsed with sterile, chilled water to remove excess milt and coelomic fluid. Eggs were then water-hardened in at least 10 volumes of cold, sterile, distilled water for $2 \mathrm{~h}$, after which they were surface-disinfected with a povidone-iodine disinfectant (Argentyne, Argent Laboratories) at $400 \mathrm{ppm}$ for $15 \mathrm{~min}$. The 3 groups of eggs were placed in separate plexiglass baskets $(8 \mathrm{~cm}$ diam., $5 \mathrm{~cm}$ deep), with a $2 \mathrm{~mm}$ plastic mesh on the bottom. Baskets were placed in a covered incubating Heath tray supplied with flowing water (2 to $4 \mathrm{l} \mathrm{min} \mathrm{m}^{-1}$ ) at $10^{\circ} \mathrm{C}$, and eggs were examined at the eyed stage to determine the numbers of survivors.

The second experiment was part of a larger study on the efficacy of antibiotics in reducing intra-ovum infections due to Rs. Eggs were taken from ripe coho salmon at Capilano Hatchery. These fish had previously been given injections of saline (controls) or of antibiotics (test fish) 2 to $3 \mathrm{wk}$ before spawning. Studies performed on the eggs and progeny from 3 of the control fish are dealt with in this paper. Eggs and milt were transported to the laboratory as already described. Fifty eggs from each fish were used. A suspension of Rs cells, prepared by the method outlined above, was injected into each of the non-water-hardened, unfertilized eggs, (1 $\mu \mathrm{l}$ $\mathrm{egg}^{-1}$ ), giving a dose of ca 10 Rs cells egg ${ }^{-1}$. The apparatus shown in Fig. 2 was used in this experiment. After injection, eggs were treated as in the first experiment except that they were surface-disinfected with a povidone-iodine solution in the form of Ovadine (Syndel Laboratories) at $500 \mathrm{ppm}$ for $10 \mathrm{~min}$. Eggs were then rinsed 3 times in at least 10 volumes of chilled, sterile water. Each egg was then carefully transferred to an individual sterile, screw-capped polystyrene testtube $(17 \times 100 \mathrm{~mm}$, Falcon), containing $5 \mathrm{ml}$ of sterile, chilled, double-distilled water. Eggs were incubated in these tubes at $9^{\circ} \mathrm{C}$ in the dark, and examined at the eyed and hatch stages for the number of survivors.

Eggs and alevins from the second experiment were assayed for viable Rs cells by removing them from testtubes, blotting them dry on sterile filter paper, and placing in clean, dry, sterile test-tubes. Eggs were pierced with a sterile needle, the contents expressed, and the 'egg shell' removed. Alevins were homogenized whole with a Polytron homogenizer (Brinkmann Instruments). Egg contents and homogenized alevins were each incubated in $5 \mathrm{ml}$ of selective broth (Austin et al. 1983) at $15^{\circ} \mathrm{C}$ for 5 to $6 \mathrm{wk}$ - this allowed any Rs cells present to be enriched to a detectable level (EveIyn et al. 1984a, b). After incubation, tubes were centrifuged at $3000 \times \mathrm{g}$ for $30 \mathrm{~min}$ to pellet Rs cells. The pellet was resuspended in $1 \mathrm{ml}$ of decanted supernatant. Twenty-five microlitres of the resulting suspension were drop-inoculated onto SKDM-C plates, and growth of Rs in these samples was expedited using the 'nurse culture' technique (Evelyn et al. 1989). Plates were incubated at $15^{\circ} \mathrm{C}$ for 2 to $3 \mathrm{wk}$ and checked for bacterial growth. Rs growth was confirmed by the indirect fluorescent antibody technique (IFAT). Results are expressed as the percentage of eggs or alevins positively identified as being infected with viable Rs.

\section{RESULTS AND DISCUSSION}

Table 1 presents the results of the microinjection experiments, and illustrates the efficacy of this technique. From Expt 1 survival to the eyed stage was good in the injected groups (73 and $80 \%$ ), although somewhat better survival was achieved in untreated control' eggs $(96 \%)$, indicating loss attributable to handling stress. In the second experiment, $45 \%$ of eggs injected with Rs survived to the eyed stage. The lower survival rate may have been due to the nature of the incubation method (in test-tubes) rather than the injection procedure itself. Incubation in test-tubes subjects the developing embryos to much lower oxygen concentrations than those encountered by eggs incubated in flowing water (Expt 1) -- concentrations that might adversely affect survival rates (Westers \& Pratt 1977). We do not think that it is likely that the lower survival rate in eggs from Expt 2 was due to the Rs cells. First, under low temperature incubation conditions the low number of Rs cells, which do not produce potent exotoxins, would grow slowly (Sanders \& Fryer 1980). Second, a pathogen that depends, to a large extent, on vertical transmission for its presence in fish populations, would not be expected to destroy its vehicle.

It was observed that when the injected and fertilized eggs were water-hardened, a 'plug' of coagulated yolk material was formed at the injection site. This plug persisted and was still evident on the yolk sac of many alevins at hatching. The size of this plug varied considerably between eggs. Other trials with the microinjection procedure (data not shown) indicated that the size of the glass needle affected both the size of the plug 
Table 1. Survival and Renibacterium salmoninarum (Rs) infection rates in coho salmon (Oncorhynchus kisutch) eggs following injection of sterile and Rs-containing solutions. P-S: Peptone-saline (0.1-0.85\%, w/v); na: not applicable

\begin{tabular}{|c|c|c|c|c|c|}
\hline \multirow[t]{2}{*}{ Expt } & \multirow[t]{2}{*}{ Egg Treatment } & \multirow[t]{2}{*}{ Incubation } & \multirow{2}{*}{$\begin{array}{l}\% \text { Survival at eyed } \\
\text { stage }\end{array}$} & \multicolumn{2}{|c|}{$\%$ Infected with $\mathrm{Rs}^{d}$} \\
\hline & & & & Eyed & Alevin \\
\hline 1 & Injected with P-S & $\begin{array}{l}\text { Heath tray (flowing } \\
\text { water at } 10^{\circ} \mathrm{C} \text { ) }\end{array}$ & 73 & na & na \\
\hline 1 & Punctured only & $\begin{array}{l}\text { Heath tray (flowing } \\
\text { water at } 10^{\circ} \mathrm{C} \text { ) }\end{array}$ & 80 & na & na \\
\hline 1 & Untreated & $\begin{array}{l}\text { Heath tray (flowing } \\
\text { water at } 10^{\circ} \mathrm{C} \text { ) }\end{array}$ & 96 & na & na \\
\hline 2 & $\begin{array}{l}\text { Injected with Rs } \\
\text { cells in P-S }\end{array}$ & $\begin{array}{l}\text { Polystyrene test-tube } \\
\text { (static water at } 9^{\circ} \mathrm{C} \text { ) }\end{array}$ & 45 & 91 & 82 \\
\hline
\end{tabular}

and egg mortality. The use of glass needles with a bore size $>10 \mu \mathrm{m}$ resulted in large plugs and low survival rates $>50 \%$ of the eggs injected with such needles turned opaque, indicating death, during the waterhardening step). None of the eggs injected with such needles survived to the eyed stage.

Another factor affecting egg survival appeared to be the time that elapsed between injection and waterhardening. During this period, extensive 'haemorrhaging ' of yolk material sometimes occurred, and increased mortality rates resulted if water-hardening was delayed for more than 5 to $10 \mathrm{~min}$. We conclude that egg survival can be maximized when microinjecting eggs by using glass needles of sufficiently small bore $(10$ to $50 \mu \mathrm{m})$ and by ensuring that the time between injection and waterhardening is as short as possible $(<10 \mathrm{~min})$.

From Table 1 it can be seen that in the second experiment, viable Rs cells were recovered from $91 \%$ of eyed eggs assayed and from $82 \%$ of the tested alevins. These eggs were taken from coho salmon which, as mentioned before, did not show any signs of $\mathrm{Rs}$ infection. Therefore, it is concluded that the Rs growth recovered from the eggs and alevins originated from the bacterial suspension injected into the unfertilized eggs.

The microinjection technique described proved to be a simple and reliable method for ensuring high intraovum infection rates. The procedure should, therefore, greatly facilitate studies now underway to evaluate methods for preventing vertical transmission of pathogens.

The procedure need not be limited to the injection of infectious agents. If the target location within the egg is large (e.g, the yolk), rather than small (e.g. the perivitelline space; Metcalfe \& Sonstegard 1984, Black et al. 1985), then our technique is practicable for injection of any material into salmonid eggs and need not involve the use of costly micromanipulators.
Acknowledgements. We thank J. Ketcheson, L. ProsperiPorta, and E. Stone for their technical assistance, and D. Kowbel for kindly reviewing the manuscript. This project was supported, in part, by a grant to L. J. A. from the Natural Sciences and Engineering Research Council of Canada.

\section{LITERATURE CITED}

Austin, B., Embley, T M., Goodfellow, M. (1983). Selective isolation of Renibacterium salmoninarum. Fedn eur. microbiol. Soc. (FEMS) Lett. 17: 111-114

Black, J. J., Maccubbin, A. E., Schiffert, M. (1985). A reliable, efficient microinjection apparatus and methodology for in vivo exposure of rainbow trout and salmon embryos to chemical carcinogen. J. natn. Cancer Inst. 75: 1123-1128

Bullock, G. L., Stuckey, H. M. (1975). Fluorescent antibody identification and detection of the Corynebacterium causing kidney disease of salmonids. J. Fish. Res. Bd Can. 32: 2224-2227

Bullock, G. L., Stuckey, H. M., Mulcahy, D. (1978). Corynebacterial kidney disease: egg transmission following iodophore disinfection. Fish Health News 7: 51-52

Daly, J. G., Stevenson, R. M. W. \{1985\}. Charcoal agar, a new growth medium for the fish disease bacterium, Renibacterium salmoninarum. Appl. envir. Microbiol 50: 868-871

Evelyn, T P. T., Ketcheson, J. E., Prosperi-Porta, L. (1984a). Further evidence for the presence of Renibacterium salmoninarum in salmonid eggs and for the failure of povidone-iodine to reduce the intra-ovum infection rate in water-hardened eggs. J. Fish Dis. 7: 173-182

Evelyn, T P. T., Ketcheson, J. E., Prosperi-Porta, L. (1986a). Use of erythromycin as a means of preventing vertical transmission of Renibacterium salmoninarum. Dis. aquat. Org. 2: 7-11

Evelyn, T. P. T., Prosperi-Porta, L., Ketcheson, J. E. (1984b). The salmonid egg as a vector of the kidney disease bacterium, Renibactenum salmoninarum. In: ACUIGRUP (ed.) Fish Diseases, 4th COPRAQ Session. EDITORA ATP, Madrid, Spain, p. 111-117

Evelyn, T. P. T., Prosperi-Porta, L., Ketcheson, J. E. (1986b). Experimental intra-ovum infection of salmonid eggs with Renibactenum salmoninarum and vertical transmission of the pathogen with such eggs despite their treatment with erythromycin. Dis. aquat. Org. 1 197-202 
Evelyn, T P. T., Prosperi-Porta, L., Katcheson, J. E. (1986c). Persistence of the kidney disease bacterium, Renibacterium salmoninarum, in coho salmon, Oncorhynchus kisutch (Walbaum), eggs treated during and after waterhardening with povidone-iodine. J. Fish Dis. 9: 461-464

Evelyn, T P. T., Bell, G. R., Prosperi-Porta, L., Ketcheson, J. E. (1989). A simple technique for accelerating the growth of the kidney disease bacterium Renibacterium salmoninarum on a commonly used culture medium (KDM2). Dis. aquat. Org. $7 \cdot 231-234$

Editorial responsibility: Managing Editor
Metcalfe, C. D., Sonstegard, R. A. (1984). Microinjection of carcinogens into rainbow trout embryos: an in vivo carcinogenesis assay. J. natn. Cancer Inst. 73: 1125-1132

Sanders, J. E., Fryer, J. L. (1980). Renibacterium salmoninarum gen. nov., sp. nov., the causative agent of bacterial kidney disease in salmonid fishes. Int. J. system Bact. 30: 496-502

Westers, H., Pratt, K. M. (1977). Rational design of hatcheries for intensive salmonid culture based on metabolic characteristics. Prog. Fish Cult. 39: 157-165

Manuscript first received: July 21, 1989

Revised version accepted: September 22, 1989 